\title{
The Determinants of Deposit Insurance Coverage: Evidence from 74 Countries
}

\author{
Hung Ling Chen ${ }^{1}$, Edward H. Chow ${ }^{2} \&$ Wan Yu Liu ${ }^{3}$ \\ ${ }^{1}$ Department of International Business, Shih Chien University, Taiwan \\ ${ }^{2}$ Department of Finance, National Chengchi University, Taiwan \\ ${ }^{3}$ Entie Bank, Taiwan \\ Correspondence: Hung Ling Chen, Department of International Business, Shih Chien University, Taiwan. E-mail: \\ chenhub@gmail.com
}

Received: February 2, 2014

Accepted: February 24, 2014

Online Published: August 24, 2014

doi:10.5430/ijfr.v5n4p13

URL: http://dx.doi.org/10.5430/ijfr.v5n4p13

\begin{abstract}
Using data from 74 countries between the years of 1960 to 2008, we performed panel regressions and logit models on political settings and the economic situation to identify which factors influence deposit insurance coverage and the probability of changes in coverage. Results reveal that countries with higher coverage are those with less political openness, lower interest rate spreads and deposit interest rates; conversely, we find that coverage tends to be higher in countries with greater levels of government debt. Considering the time-invariant country heterogeneity, countries with lower interest rate spreads are likely to increase the coverage and the probability of changes in coverage. The results could provide reference points for policymakers in considering the setting of deposit insurance schemes, with the aim of ensuring financial stability.
\end{abstract}

Keywords: deposit insurance, coverage, political economy

\section{Introduction}

Given the substantial differences in the political structure of individual countries, the banking industry, overall economic environment, and deposit insurance systems (DIS) differ enormously from country to country. The primary aim of this study determines factors that affect deposit insurance coverage and the probability of changes in such coverage. By identifying the factors with significant influence on coverage, this research provides a new perspective to considerations for setting up DIS to ensure financial stability.

After great depression banking crisis in 1933, United States was the first to establish DIS in 1934. According to International Association of Deposit Insurers (IADI) organization's description, number of countries either establishing or considering establishing a deposit insurance system has expanded rapidly in recent years. As of 31 January 2014, 113 countries have instituted some form of explicit deposit insurance up from 12 in 1974. Another 40 countries are studying or considering the implementation of an explicit deposit insurance system. (Note 1)

According to IADI principles, the objectives of a deposit insurance system are to "protect the majority of small and unsophisticated depositors" and to "maintain depositor confidence and enhance the macroeconomic and financial stability of the banking system" (IADI, 2008). This is particularly important in times such as the financial crisis of 2008, when countries around the globe suffered from a breakdown in public confidence in the financial system as a whole.

Deposit insurance acts as a financial safety net for preventing bank runs and maintaining public confidence. Therefore, it is important for each country to have appropriate coverage according to its own situation. If coverage is too low, it fails to protect small and unsophisticated depositors. However, problems related to moral hazards are likely to occur if the level of coverage is set too high. This is because a higher level of coverage provides incentives for banks to take greater risks and the potential to lead to an overall rise in the level of instability within the financial system. Thus, regulators must identify the most suitable coverage for their country in accordance with their own country-specific characteristics.

Several previous studies have examined the relationship between deposit insurance and financial systems. For 
example, explicit deposit insurance systems raised the likelihood of distress (Hutchison and McDill, 1999; Demirgüç-Kunt and Detragiache, 1998, 2002; Chu, 2003) and had a negative impact in countries that lacked well-established bank supervision and law enforcement (Cull, Senbet and Sorge, 2005).

The factors directly influencing coverage levels or changes remain unclear. For example, the results from the application of a political economy framework undertaken by Laeven (2004) revealed that deposit insurance coverage was higher in countries dominated by poorly capitalized banks and in countries with poorly educated depositors. However, Laeven's analysis did not uncover any significant association between deposit insurance coverage and political-institutional variables, nor is there a significant association for institutional development variables. Demirgüç-Kunt, Kan, and Laeven (2008) found that countries with more-democratic environments and countries with a larger proportion of risky banks are more likely both to adopt deposit insurance and to design it with higher insurance coverage.

Our findings are distinct from the findings in the existing literature: (1) the effects of economic and political factors on the level of coverage and (2) the association of the factors and the probability of changes in coverage. In addition to employing the political-institutional variables from Laeven (2004) and Demirgüç-Kunt et al. (2008) in the current analysis, this work adds other relevant economic variables (savings rates, interest rate spreads, deposit interest rate, and government debt) to examine their effects on coverage.

As opposed to analyzing the design of deposit insurance for only a single year (2000) as in Laeven, this study used a comprehensive database that includes both cross-sectional and time-series data (74 countries from 1960 to 2008). The findings show that countries with lower interest rate spreads, lower deposit interest rate, and higher government debt levels tend to have higher coverage. Democratic countries also tend to have lower coverage levels, whereas autocratic countries tend to have higher coverage levels. Thus, our more complete dataset enabled reaching conclusions that were unavailable to Laeven.

Another significant difference exists between this paper and that of Laeven (2004) and Demirgüç-Kunt et al. (2008). The current study examined the probability of changes in deposit insurance coverage and found that countries with lower political openness, lower interest rate spreads, lower deposit interest rate, and higher government debt have a lower probability of increasing coverage levels. By considering time-invariant country heterogeneity, only lower interest rate spreads can substantially increase the changes in coverage and the probability of a coverage increase. The results should help regulators determine the appropriate level of future coverage, which might help prevent bank runs.

The remainder of this paper is organized as follows: Section 2 introduces definitions of both the data and methodology adopted for this study; Section 3 provides a discussion of the empirical results; and lastly, Section 4 offers a conclusion.

\section{Data and Methodology}

\subsection{Data}

The empirical analysis in this study primarily focuses on factors that potentially affect deposit insurance coverage. The sample data were gathered on 74 countries from 1960 to 2008. The sample descriptions are provided in Table 1.

Table 1. Sample countries description

\begin{tabular}{lccccc}
\hline & $\begin{array}{c}\text { High } \\
\text { income } \\
\text { countries }\end{array}$ & $\begin{array}{c}\text { Upper-middle } \\
\text { income } \\
\text { countries }\end{array}$ & $\begin{array}{c}\text { Lower-middle } \\
\text { income } \\
\text { countries }\end{array}$ & $\begin{array}{c}\text { Low } \\
\text { income } \\
\text { countries }\end{array}$ & Total \\
\hline Panel A: Number of countries & & & & & \\
\hline North America & 2 & & & & 2 \\
Latin America \& Caribbean & 1 & 5 & 8 & 1 & 15 \\
Western Europe & 18 & & & & 18 \\
Europe \& Central Asia & 1 & 8 & 9 & 4 & 4 \\
Africa & 2 & 2 & 3 & & 7 \\
Middle East \& North Africa & 3 & & 3 & 1 & 7 \\
East Asia \& Pacific & & & 1 & 2 & 3 \\
South Asia & & & & & 7 \\
\hline
\end{tabular}


Panel B: Ratio of deposit coverage changes for every country

\begin{tabular}{lccccc}
\hline & $\begin{array}{c}\text { High } \\
\text { income } \\
\text { countries }\end{array}$ & $\begin{array}{c}\text { Upper-middle } \\
\text { income } \\
\text { countries }\end{array}$ & $\begin{array}{c}\text { Lower-middle } \\
\text { income } \\
\text { countries }\end{array}$ & $\begin{array}{c}\text { Low } \\
\text { income } \\
\text { countries }\end{array}$ & average \\
\hline North America & 0.07 & & & & 0.07 \\
Latin America \& Caribbean & 0.00 & 0.23 & 0.31 & 1.00 & 0.31 \\
Western Europe & 0.07 & & & & 0.07 \\
Europe \& Central Asia & 0.67 & 0.44 & 0.49 & & 0.48 \\
Africa & & & & 0.05 & 0.05 \\
Middle East \& North Africa & 0.00 & 0.04 & 0.33 & & 0.15 \\
East Asia \& Pacific & 0.16 & & 0.07 & 0.25 & 0.13 \\
South Asia & & & 0.00 & 0.06 & 0.04 \\
\hline Average & 0.09 & 0.32 & 0.34 & 0.20 & 0.23 \\
\hline
\end{tabular}

The dependent variable is the extent of deposit insurance coverage, calculated as the ratio of the amount of deposit insurance coverage to per capita GDP. This ratio, which can reduce the economic scale effect for each country, has also been widely used by the International Association of Deposit Insurers ("IADI"), and by researchers examining related deposit insurance coverage issues. To support our examination of the factors that are likely to lead to changes in deposit insurance coverage, we defined another dependent variable ("CHANGE"), which is equal to 1 if the level of deposit insurance coverage has changed from the level of coverage in the previous year; otherwise, CHANGE is equal to 0 .

The countries to adopt deposit insurance were derived from Demirgüç-Kunt et al. (2008). Limited by variables and deleting fixed deposit insurance coverage during the 1960-2008 period, the final sample is 74 countries. (Note 2) The sample consists of 27 high-income countries, 15 upper-middle-income countries, 24 lower-middle-income countries, and 8 low-income countries. The independent variables are divided into two different aspects, consisting of the political setting and the overall economic environment. The economic variables were derived from the World Bank and EIU Country Data. The political variables are from the Polity IV database. All the variable definitions are provided in Table 2 .

Some of the measures used in the present study are similar to those used in Laeven (2004); however, as opposed to using variables to explain the design of deposit insurance for only a single year (2000), we extended the dataset to form longitudinal panel data which is like as Demirgüç-Kunt et al.. Not all the variables have complete data for the 49-year period, and thus, applying panel data when conducting statistical analysis increases the overall sample. Another advantage of using panel data analysis is to observe heterogeneity across countries.

Table 2. Variable definitions

\begin{tabular}{ccc}
\hline Variables & Definition & Sample \\
& Period \\
\hline
\end{tabular}

Panel A: Dependent variables

COV_GDP The ratio of the total amount of deposit insurance coverage to per-capita GDP.

$C H A \bar{N} G E \quad$ Equal to 1 if there is a change in deposit insurance coverage from the previous

1960-2008 year; otherwise equal to zero if the amount of coverage remains the same.

$1962-2008$

Panel B: Independent variables

POLITY Computed by subtracting the AUTOC score from the DEMOC score; the resulting unified polity scale ranges from +10 (strongly democratic) to -10 (strongly autocratic).

DEMOC An additive eleven-point scale (from zero to ten) derived from coding the competitiveness of political participation, openness of executive recruitment and constraints on the chief executive.

AUTOC An additive eleven-point scale (from zero to ten) derived from coding the 
competitiveness of political participation, regulation of participation, competitiveness of executive recruitment and constraints on the chief executive, using different weights.

SAVINGS

INT_SPREAD

$D E \bar{P}_{-} I N T$

GOV_DEBT
Gross savings (\% of GDP)

Interest rate spread $=$ lending rate - deposit rate $(\%)$

Deposit rate (\% per annum)

Total of domestic, external and IMF debt owed by general government ( $\%$ of GDP)
$1967-2008$

$1971-2008$

1980-2008

1980-2008

\subsection{Methodology}

Panel data were used in the analysis to understand the factors affecting deposit insurance coverage and the probability of changing deposit insurance coverage. The rationale for using panel data regression is based on determining the relationship between deposit insurance coverage vis-à-vis political and economic factors because the total amount of data available for a single year analysis is extremely limited. Analyzing panel data can increase the total number of observations covering both the time-series and cross-sectional data and account for all unobserved cross-country heterogeneity.

Two approaches are commonly used to analyze panel data: the fixed effects approach and the random effects approach. To decide between the fixed or random effects approaches, we ran the Hausman (1978) test, where the null hypothesis posits that the random effects model is the preferred model, whereas the fixed effects model is the alternative model. The results of the Hausman test in the present study clearly show the fixed effects approach to be more appropriate.

Following confirmation that the fixed effects approach is more appropriate, panel data analysis was performed using the following model:

$$
Y_{i, t}=\beta_{0}+\beta_{1} X_{1, i, t}+\ldots+\beta_{k} X_{k, i, t}+\alpha_{i}+\varepsilon_{i, t}
$$

where $Y_{i, t}$ is the dependent variable $\left(C O V_{-} G D P\right), X_{k, i, t}$ refers to the independent variables, $i$ is the country, and $t$ is the year. The independent variables consist of POLITY, DEMOC, AUTOC, SAVINGS, INT_SPREAD, DEP_INT, and $G O V_{-} D E B T . \beta_{k}$ refers to the coefficient on the independent variables, $\alpha_{i}$ is the country factors, and $\varepsilon_{i, t}$ is the error term.

To support the examination in this study of the factors likely to lead to changes in deposit insurance coverage, we employed a panel logit model, expressed as follows:

$$
L_{i, t}=\ln \left(\frac{P_{i, t}}{1-P_{i, t}}\right)=\beta_{0}+\beta_{1} X_{1, i, t}+\ldots+\beta_{k} X_{k, i, t}+u_{i, t}
$$

where $P_{i, t}$ indicates that $C H A N G E$ takes the value of 1 if a change has occurred in the level of coverage; otherwise, CHANGE takes the value of $0, L_{i, t}$ is the logit, $X_{k, i, t}$ refers to the independent variables, $i$ is the country, and $t$ is the year.

If the logit, $L_{i, t}$, is positive, then the independent variables are considered to have some influence on changes in the level of deposit insurance coverage, thereby indicating that the variable is responsible for the change in coverage.

\section{Empirical Results}

\subsection{Determinants of Deposit Insurance Coverage}

The panel data observations include both cross-sectional and time-series data aimed at identifying factors with significant influences on deposit insurance coverage. The results of the fixed effects panel regression, which includes the explanatory variables POLITY, DEMOC, AUTOC, SAVINGS, INT_SPREAD, DEP_INT, and GOV_DEBT are presented in Table 3; the dependent variable is $C O V_{-} G D P$, which is the ratio of coverage to per capita GDP.

The political-institutional variable $P O L I T Y$ was found significant with a negative coefficient, as are the economic variables INT_SPREAD and DEP_INT. The variable GOV_DEBT, which is the ratio of total government debt to GDP, was found to have a positive correlation with deposit insurance coverage, which suggests that coverage tends be higher for those countries with higher government debt levels. The coverage tends to be lower in countries with greater political openness, higher interest rate spreads, and higher deposit interest rate. These results are consistent 
with the discussions in most prior literature.

Angkinand (2005) found that political corruption was more likely to increase the probability of a banking crisis. Such countries also tend to have lower levels of political openness (Sandholtz and Kotzle, 2000), which leads to the finding that countries with lower levels of political openness are associated with higher levels of coverage. Although Laeven (2004) also found that less-democratic countries have higher coverage ratio but have little power in explaining variation in $C O V_{-} G D P$, the use of longitudinal panel data found that political openness could affect the coverage level. On the other side, Demirgüç-Kunt et al. (2008) found that countries with more-democratic environments are more likely both to adopt deposit insurance and to design it with higher coverage ratio. But the effect of political openness on coverage ratio is weak significantly after adopting a system of explicit deposit insurance. (Note 3)

Table 3. Panel regression results of the determinants of deposit insurance coverage

\begin{tabular}{|c|c|c|c|c|c|c|}
\hline \multirow{2}{*}{ Variable } & \multicolumn{6}{|c|}{ Models } \\
\hline & (1) & (2) & (3) & (4) & (5) & (6) \\
\hline POLITY & $\begin{array}{l}-0.214 \\
(0.000) * * *\end{array}$ & & & $\begin{array}{l}-0.201 \\
(0.000) * * *\end{array}$ & & \\
\hline$D E M O C$ & & $\begin{array}{l}-0.217 \\
(0.022) * *\end{array}$ & & & $\begin{array}{l}-0.193 \\
(0.035) * *\end{array}$ & \\
\hline AUTOC & & & $\begin{array}{l}0.534 \\
(0.000) * * *\end{array}$ & & & $\begin{array}{c}0.503 \\
(0.000) * * *\end{array}$ \\
\hline SAVINGS & $\begin{array}{r}-0.016 \\
(0.582)\end{array}$ & $\begin{array}{l}-0.026 \\
(0.379)\end{array}$ & $\begin{array}{r}0.004 \\
(0.893)\end{array}$ & $\begin{array}{r}-0.010 \\
(0.719)\end{array}$ & $\begin{array}{c}-0.018 \\
(0.516)\end{array}$ & $\begin{array}{r}0.007 \\
(0.802)\end{array}$ \\
\hline INT_SPREAD & $\begin{array}{l}-0.048 \\
(0.000) * * *\end{array}$ & $\begin{array}{l}-0.048 \\
(0.000) * * *\end{array}$ & $\begin{array}{l}-0.048 \\
(0.000) * * *\end{array}$ & & & \\
\hline$D E P_{-} I N T$ & & & & $\begin{array}{l}-0.059 \\
(0.003) * * *\end{array}$ & $\begin{array}{l}-0.061 \\
(0.002) * * *\end{array}$ & $\begin{array}{l}-0.054 \\
(0.005) * * *\end{array}$ \\
\hline$G O V_{-} D E B T$ & $\begin{array}{c}0.037 \\
(0.000) * * *\end{array}$ & $\begin{array}{c}0.037 \\
(0.000) * * *\end{array}$ & $\begin{array}{c}0.038 \\
(0.000) * * *\end{array}$ & $\begin{array}{c}0.028 \\
(0.000) * * *\end{array}$ & $\begin{array}{c}0.029 \\
(0.000) * * *\end{array}$ & $\begin{array}{c}0.029 \\
(0.000) * * *\end{array}$ \\
\hline Intercept & $\begin{array}{r}1.173 \\
(0.469)\end{array}$ & $\begin{array}{c}2.922 \\
(0.063) *\end{array}$ & $\begin{array}{l}-1.718 \\
(0.332)\end{array}$ & $\begin{array}{r}1.649 \\
(0.277)\end{array}$ & $\begin{array}{c}3.258 \\
(0.027) * *\end{array}$ & $\begin{array}{l}-1.011 \\
(0.543)\end{array}$ \\
\hline Hausman Test & $\begin{array}{l}13.754 \\
(0.003) * * *\end{array}$ & $\begin{array}{l}16.237 \\
(0.001) * * *\end{array}$ & $\begin{array}{l}24.490 \\
(0.000) * * *\end{array}$ & $\begin{array}{l}34.911 \\
(0.000) * * *\end{array}$ & $\begin{array}{l}37.303 \\
(0.000) * * *\end{array}$ & $\begin{array}{l}34.436 \\
(0.000) * * *\end{array}$ \\
\hline No. of Obs. & 574 & 574 & 574 & 627 & 627 & 627 \\
\hline
\end{tabular}

Notes: The dependent variable GOV_GDP is the ratio of coverage to per-capita GDP (refer to Table 2 for the definitions of the independent variables); figures in parentheses are $p$-values. * indicates significance at the $10 \%$ level; ** indicates significance at the $5 \%$ level; and *** indicates significance at the $1 \%$ level. The null hypothesis of the Hausman test is for random effects.

In addition to the discussion on the relationship between political openness and coverage, Laeven (2002) indicated that higher deposit insurance coverage would also result in higher costs (premiums). Zarruk and Madura (1992) found that countries with higher deposit insurance costs would invariably have lower interest rate spreads, thereby supporting our finding that countries with lower interest rate spreads generally have higher levels of coverage.

The panel regression further indicates a negative correlation between the deposit interest rate and coverage. The finding is inconsistent with Demirgüç-Kunt and Detragiache (1998) because they suggested that nominal interest rate is highly significant in increasing banking sector fragility. To prevent instability and panic, most countries tend to have higher coverage to ensure that their depositors are relatively safe, and the coefficients of government debt are significantly positive. This means that countries with higher government debt levels tend to have lower credibility and are associated with relatively greater risk. Thus, coverage tends to be higher for countries with higher government debt levels.

In summary, we found that countries with less political openness, lower interest rate spreads, lower deposit interest rate, and higher government debt tend to have higher coverage. This is consistent with the findings in prior literature that countries with deposit insurance systems tend to suffer from financial instability. (Note 4) 


\subsection{Probability Determinants of Changing Deposit Insurance Coverage}

This work adopted the panel logit model to determine factors that affect the probability of changes in coverage. As shown in Table 1 Panel B, countries with both upper-middle-income levels (39\%) and lower-middle-income levels (34\%) tend to change their coverage more often than those with either high-income levels $(13 \%)$ or low-income levels $(19 \%)$.

The panel logit model results presented in Table 4 reveal that the GOV DEBT variable shows a significant decrease in the probability of a change in coverage. The INT_SPREAD and DEP INT variables have a significant positive effect, which means that countries with higher interest rate spread or higher deposit interest rate have a higher probability of changing their coverage level. We take the result of Model (1) in Table 4 as an example for our examination of the marginal effect on change in coverage. By applying the coefficients into the panel logit model, we obtain the following equation:

$$
\begin{aligned}
L_{i, t}= & \ln \left(\frac{P_{i, t}}{1-P_{i, t}}\right)=0.056 \times \text { POLITY }_{i, t}+0.016 \times \operatorname{SAVING}_{i, t} \\
& +0.041 \times I N T_{-} S P R E A D_{i, t}-0.027 \times G O V_{-} D E B T_{i, t}-1.140+u_{i, t}
\end{aligned}
$$

Thereafter, we can also calculate the increment in the probability of change $\left(P_{i, t}\right)$ for a single unit increase in the $G O V \_D E B T$ variable. The calculation is expressed as follows:

$$
\frac{P_{i, t}}{1-P_{i, t}}=e^{-0.027 \times G O V_{-} D E B T}=e^{-0.027 \times 1}=0.99 \Rightarrow P_{i, t}=\frac{1}{1+0.99}=0.51
$$

The marginal effect is determined as

\begin{tabular}{|c|c|c|c|c|c|c|}
\hline \multirow{2}{*}{ Variable } & \multicolumn{6}{|c|}{ Models } \\
\hline & (1) & (2) & (3) & (4) & (5) & (6) \\
\hline POLITY & $\begin{array}{c}0.056 \\
(0.053) *\end{array}$ & & & $\begin{array}{r}0.029 \\
(0.227)\end{array}$ & & \\
\hline DEMOC & & $\begin{array}{r}0.061 \\
(0.147)\end{array}$ & & & $\begin{array}{r}0.022 \\
(0.550)\end{array}$ & \\
\hline AUTOC & & & $\begin{array}{c}-0.182 \\
(0.021) * *\end{array}$ & & & $\begin{array}{c}-0.124 \\
(0.055) *\end{array}$ \\
\hline SAVINGS & $\begin{array}{r}0.016 \\
(0.281)\end{array}$ & $\begin{array}{r}0.017 \\
(0.249)\end{array}$ & $\begin{array}{r}0.016 \\
(0.266)\end{array}$ & $\begin{array}{r}0.010 \\
(0.471)\end{array}$ & $\begin{array}{r}0.011 \\
(0.416)\end{array}$ & $\begin{array}{r}0.010 \\
(0.485)\end{array}$ \\
\hline INT_SPREAD & $\begin{array}{c}0.041 \\
(0.000) * * *\end{array}$ & $\begin{array}{c}0.041 \\
(0.000) * * *\end{array}$ & $\begin{array}{c}0.039 \\
(0.000) * * *\end{array}$ & & & \\
\hline DEP_INT & & & & $\begin{array}{l}0.040 \\
(0.000) * * *\end{array}$ & $\begin{array}{l}0.040 \\
(0.000) * * *\end{array}$ & $\begin{array}{l}0.038 \\
(0.000) * * *\end{array}$ \\
\hline GOV_DEBT & $\begin{array}{l}-0.027 \\
(0.000) * * *\end{array}$ & $\begin{array}{l}-0.027 \\
(0.000) * * *\end{array}$ & $\begin{array}{l}-0.026 \\
(0.000) * * *\end{array}$ & $\begin{array}{l}-0.022 \\
(0.000) * * *\end{array}$ & $\begin{array}{l}-0.022 \\
(0.000) * * *\end{array}$ & $\begin{array}{l}-0.022 \\
(0.000) * * *\end{array}$ \\
\hline Intercept & $\begin{array}{l}-1.140 \\
(0.006) * * *\end{array}$ & $\begin{array}{l}-1.233 \\
(0.009) * * *\end{array}$ & $\begin{array}{c}-0.639 \\
(0.094) *\end{array}$ & $\begin{array}{l}-1.118 \\
(0.008) * * *\end{array}$ & $\begin{array}{l}-1.107 \\
(0.018) * *\end{array}$ & $\begin{array}{l}-0.805 \\
(0.047) * *\end{array}$ \\
\hline $\begin{array}{l}\text { Wald } \\
\text { Chi-Square }\end{array}$ & $\begin{array}{l}40.986 \\
(0.000) * * *\end{array}$ & $\begin{array}{l}39.349 \\
(0.000) * * *\end{array}$ & $\begin{array}{l}43.203 \\
(0.000) * * *\end{array}$ & $\begin{array}{l}40.618 \\
(0.000) * * *\end{array}$ & $\begin{array}{l}39.606 \\
(0.000) * * *\end{array}$ & $\begin{array}{l}43.103 \\
(0.000) * * *\end{array}$ \\
\hline No. of Obs. & 580 & 580 & 580 & 663 & 663 & 663 \\
\hline
\end{tabular}

$$
\beta_{1} \times P_{i, t} \times\left(1-P_{i, t}\right)=-0.027 \times 0.51 \times 0.49=-0.00675
$$

Table 4. Panel logit model results of the CHANGE variable

Notes: The dependent variable $C H A N G E$ is a dummy variable which is equal to 1 if there has been a change in coverage as compared to the previous year; otherwise zero (refer to Table 2 for the definitions of the independent variables); figures in parentheses are $p$-values. $*$ indicates significance at the $10 \%$ level; $* *$ indicates significance at the $5 \%$ level; and $* * *$ indicates significance at the $1 \%$ level.

This can be interpreted as a single unit increase in government debt, leading to a decrease in the probability of a change in coverage. Based on our data, we observe that a change in coverage typically involves an increase in the 
level of coverage. From all the observations of changes in the level of deposit insurance coverage examined in this study, only 18 resulted in any reduction in insurance coverage. We interpret this to mean that an increase in government debt reduces the probability of any increase in coverage.

According to the IADI, (Note 5) "relying on the government to support a higher coverage level creates a fiscal burden for the government." Because Table 3 shows that countries with higher government debt levels already have higher coverage ratios, it is not surprising that Table 4 shows these countries to have a lower probability of raising their coverage levels because their fiscal burdens are already too high.

\subsection{Determinants of Change in Deposit Insurance Coverage}

Table 5 shows the logit model of the probability of changes in coverage on the changes in independent variables. An examination of factors likely to affect the probability of changes in coverage shows that an increase in changes of interest rate spread (d_INT_SPREAD), deposit interest rate $\left(d_{-} D E P_{-} I N T\right)$, and government debt $\left(d_{-} G O V_{-} D E B T\right)$ tends to reduce the probability of any increase in coverage.

Table 5. Logit model of changes in deposit insurance coverage

\begin{tabular}{|c|c|c|c|c|c|c|}
\hline \multirow{2}{*}{ Variable } & \multicolumn{6}{|c|}{ Models } \\
\hline & (1) & (2) & (3) & (4) & (5) & (6) \\
\hline \multirow{2}{*}{$d_{-}$POLITY } & -0.024 & & & 0.071 & & \\
\hline & $(0.935)$ & & & $(0.756)$ & & \\
\hline \multirow{2}{*}{$d_{-} D E M O C$} & & -0.003 & & & 0.183 & \\
\hline & & $(0.995)$ & & & $(0.612)$ & \\
\hline \multirow{2}{*}{$d_{-} A U T O C$} & & & 0.141 & & & -0.019 \\
\hline & & & $(0.853)$ & & & $(0.974)$ \\
\hline \multirow{2}{*}{$d \_S A V I N G S$} & 0.105 & 0.076 & 0.122 & 0.103 & 0.075 & 0.124 \\
\hline & $(0.588)$ & $(0.693)$ & $(0.529)$ & $(0.592)$ & $(0.699)$ & $(0.517)$ \\
\hline \multirow{2}{*}{ d_INT_SPREAD } & -3.112 & -3.111 & -3.100 & & & \\
\hline & $(0.024) * *$ & $(0.024) * *$ & $(0.024) * *$ & & & \\
\hline \multirow{2}{*}{$d_{-} D E P_{-} I N T$} & & & & -2.317 & -2.338 & -2.332 \\
\hline & & & & $(0.027) * *$ & $(0.026) * *$ & $(0.028) * *$ \\
\hline \multirow{2}{*}{$d_{-} G O V \_D E B T$} & -1.900 & -1.939 & -1.820 & -5.503 & -5.564 & -5.494 \\
\hline & $(0.357)$ & $(0.342)$ & $(0.384)$ & $(0.002) * * *$ & $(0.002) * * *$ & $(0.002) * * *$ \\
\hline \multirow{2}{*}{ Intercept } & -2.358 & -2.361 & -2.352 & -2.510 & -2.519 & -2.504 \\
\hline & $(0.000) * * *$ & $(0.000)^{* * *}$ & $(0.000) * * *$ & $(0.000) * * *$ & $(0.000) * * *$ & $(0.000) * * *$ \\
\hline Wald & 11.790 & 11.790 & 11.836 & 13.857 & 13.931 & 13.862 \\
\hline Chi-Square & $(0.019) * *$ & $(0.019) * *$ & $(0.019) * *$ & $(0.008) * * *$ & $(0.008) * * *$ & $(0.008) * * *$ \\
\hline No. of Obs. & 501 & 501 & 501 & 555 & 555 & 555 \\
\hline
\end{tabular}

Notes: The dependent variable CHANGE is a dummy variable which is equal to 1 if there has been a change in coverage as compared to the previous year; otherwise zero (refer to Table 2 for the definitions of the independent variables); figures in parentheses are $p$-values. $*$ indicates significance at the $10 \%$ level; $* *$ indicates significance at the $5 \%$ level; and $* * *$ indicates significance at the $1 \%$ level.

This study also conducted a random effects panel regression to examine changes in independent variables arising from changes in the level of deposit insurance coverage (d_cov_gdp). Table 6 indicates that only changes in interest spreads (d_INT_SPREAD) have negative effects on changes in coverage once time-invariant country heterogeneity is accounted for, which is consistent with the results reported in Table 3 and Table 5. This indicates the strongly negative significance of the relationship between changes of interest rate spreads and changes of coverage over per capita GDP, which is consistent with the report by Zarruk and Madura (1992). Countries with lower interest rate spread (INT_SPREAD) have higher levels of coverage and a lower probability of changing coverage. Countries increase changes of deposit insurance coverage and the probability of changes in coverage when they decrease interest rate spreads (d_INT_SPREAD). 
Table 6. Panel regression of changes in influential factors

\begin{tabular}{|c|c|c|c|c|c|c|}
\hline \multirow{2}{*}{ Variable } & \multicolumn{6}{|c|}{ Models } \\
\hline & (1) & (2) & (3) & (4) & (5) & (6) \\
\hline$d_{-}$POLITY & $\begin{array}{l}-0.005 \\
(0.807)\end{array}$ & & & $\begin{array}{r}-0.005 \\
(0.813)\end{array}$ & & \\
\hline$d_{-} D E M O C$ & & $\begin{array}{r}-0.020 \\
(0.595)\end{array}$ & & & $\begin{array}{r}-0.017 \\
(0.657)\end{array}$ & \\
\hline d_AUTOC & & & $\begin{array}{r}-0.009 \\
(0.862)\end{array}$ & & & $\begin{array}{c}-0.003 \\
(0.949)\end{array}$ \\
\hline d_SAVINGS & $\begin{array}{r}0.018 \\
(0.341)\end{array}$ & $\begin{array}{r}0.019 \\
(0.323)\end{array}$ & $\begin{array}{r}0.017 \\
(0.359)\end{array}$ & $\begin{array}{r}0.004 \\
(0.792)\end{array}$ & $\begin{array}{r}0.005 \\
(0.775)\end{array}$ & $\begin{array}{r}0.004 \\
(0.809)\end{array}$ \\
\hline d_INT_SPREAD & 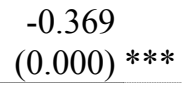 & $\begin{array}{l}-0.369 \\
(0.000) * * *\end{array}$ & $\begin{array}{l}-0.370 \\
(0.000) * * *\end{array}$ & & & \\
\hline$d_{-} D E P_{-} I N T$ & & & & $\begin{array}{r}-0.033 \\
(0.510)\end{array}$ & $\begin{array}{r}-0.033 \\
(0.512)\end{array}$ & $\begin{array}{c}-0.033 \\
(0.518)\end{array}$ \\
\hline$d_{-} G O V \_D E B T$ & $\begin{array}{r}0.074 \\
(0.681) \\
\end{array}$ & $\begin{array}{r}0.078 \\
(0.665)\end{array}$ & $\begin{array}{r}0.071 \\
(0.693)\end{array}$ & $\begin{array}{r}0.074 \\
(0.639)\end{array}$ & $\begin{array}{r}0.077 \\
(0.627)\end{array}$ & $\begin{array}{r}0.073 \\
(0.646)\end{array}$ \\
\hline Intercept & $\begin{array}{r}-0.022 \\
(0.385) \\
\end{array}$ & $\begin{array}{r}-0.022 \\
(0.389)\end{array}$ & $\begin{array}{r}-0.023 \\
(0.368)\end{array}$ & $\begin{array}{r}-0.019 \\
(0.488)\end{array}$ & $\begin{array}{r}-0.019 \\
(0.491)\end{array}$ & $\begin{array}{r}-0.019 \\
(0.481)\end{array}$ \\
\hline Hausman Test & $\begin{array}{r}3.601 \\
(0.463) \\
\end{array}$ & $\begin{array}{r}4.401 \\
(0.354) \\
\end{array}$ & $\begin{array}{r}3.063 \\
(0.547) \\
\end{array}$ & $\begin{array}{r}2.183 \\
(0.702) \\
\end{array}$ & $\begin{array}{r}2.584 \\
(0.630) \\
\end{array}$ & $\begin{array}{r}1.860 \\
(0.761)\end{array}$ \\
\hline No. of Obs. & 487 & 487 & 487 & 539 & 539 & 539 \\
\hline
\end{tabular}

Notes: The dependent variable d_GOV_GDP is the changes ratio of coverage to per-capita GDP (refer to Table 2 for the definitions of the independent variables); figures in parentheses are $p$-values. * indicates significance at the $10 \%$ level; ** indicates significance at the $5 \%$ level; and $* * *$ indicates significance at the $1 \%$ level. The Hausman Test is for random effects. The null hypothesis of $\mathrm{F}$ Test is no fixed effects

\section{Conclusion}

This study focuses on finding the relationship between economic and political factors and the level of coverage, and determines factors that affect the probability of changes in coverage. Using panel data, we found that countries with lower interest rate spreads, lower deposit interest rate, and higher government debt levels tend to have higher coverage. Democratic (autocratic) countries also tend to have lower (higher) coverage levels.

Our more complete dataset enabled us to reach findings that were unavailable to Laeven. From the panel logit analysis, we found that countries with lower political openness, lower interest rate spreads and deposit interest rate, and higher government debt reduce the probability of changes in coverage. A decrease in interest rate spreads, deposit interest rate, and government debt increases the probability of changes in coverage. Finally, only changes in interest rate spreads can explain changes in coverage after accounting for time-invariant country heterogeneity, which is another significant difference between our paper and the Laeven study. In summary, our findings provide a useful reference for regulators in setting coverage levels.

\section{References}

Angkinand, A. (2005). Deposit insurance and financial crises: Investigation of the cost benefit tradeoff. Working Paper, Claremont Centre for Economic Policy Studies, Claremont Graduate University.

Chu, K. H. (2003). Deposit insurance and banking crises in the short and long run. Cato Journal, 32, 265-280.

Cull, R., Senbet, L. W., \& Sorge, M. (2005). Deposit insurance and financial development. Journal of Money Credit, and Banking, 37, 43-82. http://dx.doi.org/10.1353/mcb.2005.0004

Demirgüç-Kunt, A., \& Detragiache, E. (1998). The determinants of banking crises in developing and developed countries. International Monetary Fund Staff Papers, 45, 81-109. http://dx.doi.org/10.2307/3867330

Demirgüç-Kunt, A., \& Detragiache, E. (2002). Does deposit insurance increase banking system stability? An empirical investigation. Journal of Monetary Economics, 49, 1373-1406. http://dx.doi.org/10.1016/S0304-3932(02)00171-X

Demirgüç-Kunt, A., Kane, E. J., \& Laeven, L. (2008). Determinants of deposit-insurance adoption and design, 
Journal of Financial Intermediation, 17, 407-438. http://dx.doi.org/10.1016/j.jfi.2007.03.009

Hausman, J. A. (1978). Specification tests in econometrics. Econometrica, 46, 1251-1271. http://dx.doi.org/10.2307/1913827

Hutchison, M., \& McDill, K. (1999). Are all banking crises alike? The Japanese experience in international comparison. Journal of the Japanese and International Economies, 13, 155-180. http://dx.doi.org/10.1006/jjie.1999.0427

Laeven, L. (2002). Pricing of deposit insurance. Working paper, World Bank Policy Research Working Paper No. 2871. http://dx.doi.org/10.1596/1813-9450-2871

Laeven, L. (2004). The political economy of deposit insurance. Journal of Financial Services Research, 26, 201-224. http://dx.doi.org/10.1023/B:FINA.0000040049.53563.e1

Sandholtz, W. \& Koetzle, W. (2000). Accounting for corruption: Economic structure, democracy, and trade. International Studies Quarterly, 44, 31-50. http://dx.doi.org/10.1111/0020-8833.00147

Zarruk, E. R., \& Madura, J. (1992). Optimal bank interest margin under capital regulation and deposit insurance. Journal of Financial and Quantitative Analysis, 27, 143-149. http://dx.doi.org/10.2307/2331303

\section{Notes}

Note 1. IADI website http://www.iadi.org/di.aspx

Note 2. Demirgüç-Kunt et al. (2008) used 181 countries during the 1960-2003 period to identify factors that influence decisions about a country's adopting deposit insurance. Of these countries, 87 have adopted explicit deposit insurance. We used those 87 countries data and extended the sample period through 2008 to incorporate data on recent adopters.

Note 3. In page 433 of Demirgüç-Kunt et al. (2008), the coefficient of Polity score in model (1) is 0.097 and significant at $10 \%$.

Note 4. Hutchison and McDill (1999), Demirgüç-Kunt and Detragiache (2002), Chu (2003), and Cull et al. (2005).

Note 5. International Association of Deposit Insurers (IADI) website http://www.iadi.org/di.aspx 